University of Nebraska - Lincoln

DigitalCommons@University of Nebraska - Lincoln

USDA Forest Service / UNL Faculty Publications U.S. Department of Agriculture: Forest Service --

National Agroforestry Center

2012

Stochastic and deterministic processes regulate spatio-temporal variation in seed bank diversity

Alejandro A. Royo

USDA Forest Service, aroyo@fs.fed.us

Todd E. Ristau

USDA Forest Service, tristau@fs.fed.us

Follow this and additional works at: https://digitalcommons.unl.edu/usdafsfacpub

Royo, Alejandro A. and Ristau, Todd E., "Stochastic and deterministic processes regulate spatio-temporal variation in seed bank diversity" (2012). USDA Forest Service / UNL Faculty Publications. 231.

https://digitalcommons.unl.edu/usdafsfacpub/231

This Article is brought to you for free and open access by the U.S. Department of Agriculture: Forest Service -National Agroforestry Center at DigitalCommons@University of Nebraska - Lincoln. It has been accepted for inclusion in USDA Forest Service / UNL Faculty Publications by an authorized administrator of DigitalCommons@University of Nebraska - Lincoln. 


\title{
Stochastic and deterministic processes regulate spatio-temporal variation in seed bank diversity
}

\author{
Alejandro A. Royo \& Todd E. Ristau
}

Keywords

$\alpha$ - and $\beta$-diversity; assembly; disturbance; seed

longevity; temperate forests

Nomenclature

USDA Plants Database (USDA NRCS 2012)

Received 3 August 2012

Accepted 2 October 2012

Co-ordinating Editor: Beverly Collins

Royo, A.A. (corresponding author, aroyo@fs. fed.us) \& Ristau, T.E. (tristau@fs.fed.us): USDA Forest Service, Northern Research Station, PO Box 267, Irvine, PA, 16329-0267, USA

\section{Introduction}

Elucidating the rates, patterns and processes underlying shifts in community composition over space and time is

\begin{abstract}
Question: Seed banks often serve as reservoirs of taxonomic and genetic diversity that buffer plant populations and influence post-disturbance vegetation trajectories; yet evaluating their importance requires understanding how their composition varies within and across spatial and temporal scales $(\alpha-$ and $\beta$-diversity). Shifts in seed bank diversity are strongly governed by the deterministic role of differential seed longevities. Nevertheless, spatio-temporal variability in propagule depletion from and recruitment into seed banks may alter both $\alpha$ - and $\beta$-diversity. Here, we ask to what degree deterministic seed exhaustion, stochasticity in recruitment and mortality, or both, shape $\alpha$ - and $\beta$-diversity?
\end{abstract}

Location: Temperate hardwood forest stands of varying ages in northern Pennsylvania, USA.

Methods: We surveyed the seed bank and herbaceous vegetation communities at 39 sites and examined whether the species richness, abundance and composition of either community differs among and within sites of increasing age ranging from 43 to $106 \mathrm{yr}$ old. We explored how $\alpha$-diversity (species richness) and abundance (percentage cover, seed density) varied across the chronosequence age using regression analyses. We analysed differences in $\beta$-diversity (community composition) using permutational multivariate analyses (i.e. PERMANOVA, PERMDISP). Finally, we tested whether community composition of the herbaceous layer and seed bank communities exhibited nestedness, where nestedness refers to the degree to which less species-rich sites are a non-random subset of more species-rich sites.

Results: We found seed bank $\alpha$-diversity and abundance consistently declined across a gradient of increasingly older sites. Moreover, nestedness analyses indicated species composition at older sites represented a subset of the species found at younger sites characterized by species with persistent seeds. Nevertheless, seed bank communities demonstrated divergent compositional trajectories, whereby older sites were increasingly dissimilar, not only from younger sites, but also from each other.

Conclusions: Our results suggest that even in assemblages strongly structured by deterministic forces, such as seed banks, minor stochastic differences in colonization and extinction events may increase $\beta$-diversity over time. Therefore, we argue deterministic and stochastic processes are complementary factors governing post-disturbance turnover in species assemblages, and suggest that seed banks contribute to species' persistence and overall forest community diversity across space and time. 
the relative importance of deterministic, niche-based processes (e.g. competition, predation) vs stochastic or neutral processes (e.g. dispersal, colonization, extinctions) in determining patterns of species co-existence (Chesson 2000; Hubbell 2001; Chase \& Myers 2011). This debate continues unabated, but most communities are likely structured through varying degrees of both deterministic and stochastic processes (Adler et al. 2007; Purves \& Turnbull 2010).

In temperate forests, considerable research has focused on understorey plant species community dynamics following disturbance (Roberts 2004; Vellend et al. 2007; Baeten et al. 2010; Dovčiak \& Halpern 2010; Bruelheide et al. 2011). Decades of post-disturbance responses in the taxonomically diverse herbaceous layer in forests repeatedly demonstrate that deterministic forces, including changing light regimes and inter-specific competition determine species turnover (Oosting 1942; Christensen \& Peet 1984; Halpern 1989; Royo et al. 2011; reviewed in Roberts \& Gilliam 2003). In contrast, the dynamics of temperate forest seed banks - buried viable seeds in soil (sensu Thompson \& Grime 1979) - have received comparatively little attention. This disparity in research attention is somewhat surprising given that seed banks contribute to the maintenance of forest plant diversity by serving as taxonomic and genetic reservoirs and buffering plant populations through disturbance events or adverse conditions (reviewed in Leck et al. 1989). Additionally, seed bank communities differ from the herbaceous layer vegetation in several ways that may greatly affect the degree to which deterministic vs stochastic events influence community dynamics.

In stark contrast to the dynamic shifts observed in herbaceous layer composition following disturbance, including the waxing and waning of species, temperate forest seed bank communities in the decades following disturbance are more likely characterized by progressive disassembly (sensu Zavaleta et al. 2009), wherein the relatively fixed community reservoir established early in succession is progressively depleted over time (Nakagoshi 1985; Pickett \& McDonnell 1989; Peterson \& Carson 1996; reviewed in Bossuyt \& Hermy 2001). Although changes in richness and composition may result from stochastic colonization and extinction events (e.g. germination; Hyatt $\&$ Casper 2000), intra-specific differences in seed persistence (i.e. longevity) are generally the factors driving the deterministic species attrition (Livingston \& Allessio 1968; Schiffman \& Johnson 1992). A robust understanding of seed bank compositional shifts following forest disturbance, however, remains lacking due to the paucity of well-replicated chronosequence studies (but see Van Calster et al. 2008; Plue et al. 2010a). Determining the degree of variation in species composition, both across time and among sites, is essential for understanding how seed banks influence vegetation response and recovery from disturbance (Leckie et al. 2000; Decocq et al. 2004; Suding et al. 2004).

The role of deterministic vs stochastic processes for compositional dynamics of forest seed banks could yield at least two fundamentally different outcomes. On the one hand, if the deterministic process of differential seed longevities predominates, seed bank communities not only should experience declines in richness and abundance, but could grow increasingly homogenized as composition converges towards the narrow set of species possessing the most persistent seeds (Van Calster et al. 2008; Plue et al. 2010a; see also Dupuy \& Chazdon 1998). Alternatively, if stochastic events or local biotic and abiotic factors (e.g. light availability, soil moisture) govern propagule depletion from and recruitment into the seed bank (or both), then richness and abundance declines may be negligible or unpredictable and seed bank community composition will exhibit greater variability over time (Marquis 1975b; Granstrom 1987; Kjellsson 1992; Jankowska-Błaszczuk et al. 1998; Leckie et al. 2000; Bossuyt \& Hermy 2001). These two views generate contrasting patterns of alpha $(\alpha$; within patch) and beta ( $\beta$; among patch) diversity. The first predicts consistent decreases in both $\alpha$ - and $\beta$-diversity with an increasingly nested species composition (Wright et al. 1998), while the second predicts modest declines, if any, in $\alpha$-diversity and increases in $\beta$-diversity.

\section{Methods}

\section{Study sites and sampling}

We surveyed forested areas throughout a $240-\mathrm{km}$ swath of forest land in northern and northwestern Pennsylvania, USA, to locate second-growth stratified-mixed hardwood stands (sensu Smith 1986), ranging from 43 to 106 yr since stand establishment The region is dominated by contiguous even-aged forests that originated from widespread clear-cutting between 1890 and 1930 (Marquis 1975a). The area has a humid temperate climate; annual precipitation averages $1077 \mathrm{~mm}$, summer temperatures average $18.6^{\circ} \mathrm{C}$, and growing seasons last 100-130 d (Whitney 1990). All sites were regenerating forest stands that resulted from forest harvests typical of the region (e.g. shelterwood seed cuts followed by overstorey removals; Marquis 1979) rather than post-agricultural abandonment, had not experienced any subsequent disturbance since stand origination, nor were they adjacent to any recent harvests. Thus we assumed the bulk of the long-term soil seed bank formed in the years following the stand-replacing disturbance. Thirty-nine sites were selected for the study, ranging in elevation from $319 \mathrm{~m}$ to $648 \mathrm{~m}$ (mean $=515 \mathrm{~m} \pm 52 \mathrm{SE})$. At each site, we sampled within a 0.42-ha $(60 \mathrm{~m} \times 70 \mathrm{~m})$ plot subdivided using a $10 \mathrm{~m} \times 10 \mathrm{~m}$ grid. Overstorey composition was 
quantified by measuring all trees $\geq 2.54 \mathrm{~cm} \mathrm{DBH}$ within a 0.24-ha $(40 \mathrm{~m} \times 60 \mathrm{~m})$ area nested within the 0.42-ha site, and calculated overstorey relative density. Relative density is an estimate of overstorey crowding that integrates both tree size and species identity and serves as a surrogate for light availability (Stout \& Nyland 1986). Site age was confirmed by extracting and analysing increment cores from five dominant or co-dominant trees within each stand. Sites were all characterized as mixed oak or northern hardwood stands, with overstorey composition being a mix of Acer rubrum, A. saccharum, Betula allegheniensis, B. lenta, Fagus grandifolia, Magnolia acuminata, Prunus serotina, Quercus rubra, Q. alba, Q. montana, Q. velutina and $Q$. coccinea, and various minor species.

We censused the herbaceous layer (all vascular species $\leq 1 \mathrm{~m}$ ) throughout each of the 0.42 -ha plots in the spring (1 May through 11 June) and summer (23 June through 21 July) of 2008. Inventories were conducted on $1-\mathrm{m}^{2}$ circular subplots centred on 30 randomly selected nodes out of the 64 total nodes in the grid. We estimated percentage cover for each species within the subplot visually, using cover templates for reference. Cover was estimated to the nearest percentage point if cover was $\leq 5 \%$ and was estimated to the nearest $5 \%$ thereafter. Trace amounts were noted as $0.1 \%$. A species was recorded if it fell within the subplot even if the plant was rooted outside of the plot. Because vegetation layers may overlap, it was possible to have $>100 \%$ cover on a subplot. During the spring survey, we conducted a meander search throughout the 0.42-ha plot to inventory the presence of additional species not found on subplots.

Seed bank samples were taken from each of the 30 randomly selected herbaceous subplots at each site. Soil was sampled using a $5-\mathrm{cm}$ long section of $10-\mathrm{cm}$ diameter, thin wall PVC pipe. This sampling intensity represents a total of $11775 \mathrm{~cm}^{3}$ sampled per site, which is in line with recommended sampling intensities for woodlands (Hutchings 1986) and yields a minimal seed density with a $95 \%$ confidence level of 25.4 seeds $\cdot \mathrm{m}^{2}$, provided there is a Poisson distribution (Thompson et al. 1997). Due to greenhouse space constraints, all 30 cores from within a site were bulked and thoroughly mixed; six subsamples were taken from each pooled sample for use in the seed bank emergence trials. Each subsample was placed in a $25 \mathrm{~cm} \times 25 \mathrm{~cm} \times 6 \mathrm{~cm}$ deep square tray. Trays contained ca. $2 \mathrm{~cm}$ of sterile sand covering the bottom overtopped with ca. $2.5 \mathrm{~cm}$ of subsampled soil. An additional 12 trays with only sterile sand were randomly intermixed among our sample trays to assess potential recruitment from outside sources. All 246 soil trays ( 39 sites $\times$ six subsamples +12 controls) were watered after installation, and then watered daily to prevent desiccation. As germinants emerged, they were identified to species, counted and removed from the tray. After no new germinants appeared, soil within each tray was mixed and germination tests proceeded for another month. Following this second round of germination, trays were subjected to a 90-d cold stratification period at $5{ }^{\circ} \mathrm{C}$, and then returned to the greenhouse for a final germination phase. Although we cannot definitively assess whether germinants recruited from the transient $(<1 \mathrm{yr})$ or persistent $(>1 \mathrm{yr}$; Thompson \& Grime 1979) seed bank, our sampling in mid-summer coupled with species' seed longevity suggest most germinants originated from the persistent seed bank.

At each site soil pits were excavated to a depth of up to $61 \mathrm{~cm}$ or the impermeable layer if present. Depths to horizons, mottling and impermeable layer were measured, as was the percentage of coarse fragments in each horizon. In these forests, the thin uppermost mineral horizons (A horizons) are often indistinguishable from highly decomposed organic layers (Oa horizons) and are therefore considered collectively as Oa/A. Soil from the combined Oa/A and the silicate clay, iron and aluminium oxide containing layer immediately beneath the Oa/A (B) horizons was collected, dried, and sieved using a $2-\mathrm{mm}$ sieve. Soil texture was determined using the hydrometer method (Day 1965); percentage organic matter was evaluated by loss on ignition in a muffle furnace (Allison 1965). Soil moisture was calculated using the soil water characteristics model based on texture and percentage organic matter (Saxton \& Rawls 2006). Calculated potential soil moisture available to plants (\%) was used in analyses.

\section{Statistical analyses}

We explored how patterns of seed bank and herbaceous layer $\alpha$-diversity (species richness) and abundance (cover, seed density), overstorey tree relative density and soil moisture varied across the chronosequence age using regression analyses. Regression diagnostics revealed that all dependent variables were normally distributed, and outliers and highly influential points identified by a Cook's distance $>0.1026$ were excluded from the analyses. Regression analyses of richness and abundance were conducted using the Proc Reg procedure in SAS 9.3 (SAS Institute Inc., Cary, NC, US).

We investigated whether community composition differed between the herbaceous layer and the seed bank. Moreover, we examined whether composition of the herbaceous layer and seed bank differed both among and within sites of increasing age as explicit measures of $\beta$ diversity (Anderson et al. 2011). The relatively restricted area sampled for seed banks relative to the herbaceous layer sample area may constrain detection of species with low-density seed banks (Plue et al. 2012). Thus, analyses were performed on site $\times$ species matrices where species 
present at fewer than $5 \%$ (i.e. $<3$ ) sites were omitted, as such species exert unduly large influence in multivariate analyses and distort interpretation (McCune \& Grace 2002). Furthermore, as classic similarity indices (e.g. Jaccard, Bray-Curtis) often cannot discern whether differences in $\beta$-diversity reflect differences among communities in $\alpha$-diversity or actual compositional variation, we compared community composition using the null-model Raup-Crick $\left(\beta_{\mathrm{RC}}\right)$ metric. This measure calculates similarity using a null model approach that allows the evaluation of differences in $\beta$-diversity independent of $\alpha$-diversity, and thereby reduces the possibility of spurious differences in $\beta$-diversity due to random sampling effects (Raup $\delta$ Crick 1979; Chase et al. 2011). We analysed differences in community composition using a permutational multivariate analysis of variance (PERMANOVA; Anderson 2001) with 999 permutations. Herbaceous layer vs. seed bank vegetation was compared using survey type as a categorical predictor variable. Since both types of survey were conducted within each site, we utilized site as blocking factor with the strata option in vegan package (Oksanen et al. 2012) so that randomizations were constrained within each site. Comparisons of community composition within each community type (i.e. seed bank, herbaceous layer vegetation) were also run using PERMANOVA. Here, stands from our chronosequence were binned into quintiles (43-51, 52-68, 69-79, 80-94 and $\geq 95 \mathrm{yr}$ ) to generate five groups of increasing stand age (i.e. Age $\mathrm{bins}_{\text {) }}$ ) with similar sample sizes ( $N=7$ or 8 ) in order to control for potentially spurious results due to uneven samples among bins. Nevertheless, analyses using uniformly spaced (i.e. 15-yr) intervals yielded similar results (Appendix S1). For each community we ran an omnibus PERMANOVA $(n=999$ permutations) testing the main effects and the two-way interaction of age and soil moisture potential. If a significant effect of age was found, we followed the omnibus test with Holm-Bonferroni corrected pair-wise comparisons. As tests of variation among groups in multivariate space are known to be sensitive to within-group heterogeneity, we complemented our PERMANOVA analyses with permutational analyses of multivariate dispersions (PERMDISP; Anderson et al. 2006). This test is the multivariate analogue of Levene's test and examines whether variation of replicates around the group centroid differs among groups $\left(\right.$ Age $\left._{\text {bins }}\right)$ using permutational $(n=999$ permutations) tests of significance. As in the PERMANOVA analysis, if a significant omnibus test was found, pair-wise comparisons were evaluated using Holm-Bonferroni correction.

We tested whether community composition of the herbaceous layer and seed bank communities exhibited nestedness, where nestedness refers to the degree to which less species-rich sites are a non-random subset of more species-rich sites. Nestedness analyses were evaluated using the overlap and decreasing fill method (NODF; Almeida-Neto et al. 2008; Ulrich et al. 2009). This approach is particularly powerful as it calculates nestedness independently among rows (species) and columns (sites) and allows hypothesis testing by sorting rows and/or columns along predetermined criteria, rather than marginal totals (Almeida-Neto et al. 2008). Hence, this approach allowed us to evaluate the nestedness of species composition among sites (i.e. rows) sorted by increasing age.

Finally, beyond the available information on stand origination date, disturbance history, soil moisture and overstorey relative density, we further tested the essential space-for-time substitution assumption, that sites are similar in overstorey species composition. We explored differences in overstorey species composition among our age groups $\left(\right.$ Age $_{\text {bins }}$ ) using a PERMANOVA analysis. Community composition analyses were run using the adonis, and oecosimu functions found in the vegan package of R. Species nomenclature follows USDA Plants Database (USDA NRCS 2012).

\section{Results}

Despite varying in age, our 39 chosen sites did not differ with regard to overstorey tree species composition (PERMANOVA: $F_{4,24}=1.209, \quad P=0.363 ; N=999$ permutations), overstorey relative density $\left(F_{1,36}=0.88, P=0.354\right)$ or soil moisture $\left(F_{1,37}=0.13, P=0.721\right)$. We identified 266 species across all sites in both the seed bank and the herbaceous layer (Appendix S2). The herbaceous layer contained 226 taxa, while in the seed bank, 11038 seeds representing 106 species were documented in the germination trials. Of the total taxonomic richness, only 69 taxa were shared between survey types. Dominant taxa in the seed bank were: Rubus allegheniensis, Luzula multiflora, Carex spp., Carex debilis, Betula spp. and Viola macloskeyi, which together accounted for $76.4 \%$ of germinated seedlings. $R$. allegheniensis was nearly ubiquitous; it was found in the seed bank of $37(94.8 \%)$ sites and in the above-ground vegetation of $23(58.9 \%)$ sites.

Despite sharing over a quarter of the species, the herbaceous layer and seed bank community composition were significantly different (PERMANOVA: $F_{1,77}=8.21$, $P<0.001)$. Across a gradient of increasing stand age, seed bank species richness and abundance (density) diminished $\left(P<0.0001, r^{2}=0.38\right.$ and $P=0.0009, r^{2}=0.28$, respectively; Fig. la,b). In contrast, neither richness nor abundance of the herbaceous layer varied across the stand age gradient $\left(P=0.289, r^{2}=0.03\right.$ and $P=0.99, r^{2}=0.00$, respectively). Across sites, average herbaceous layer richness was 44.12 species $\cdot$ site $^{-1} \pm 2.13$ and mean percentage cover was $45.55 \cdot \mathrm{m}^{-2} \pm 3.70$. 

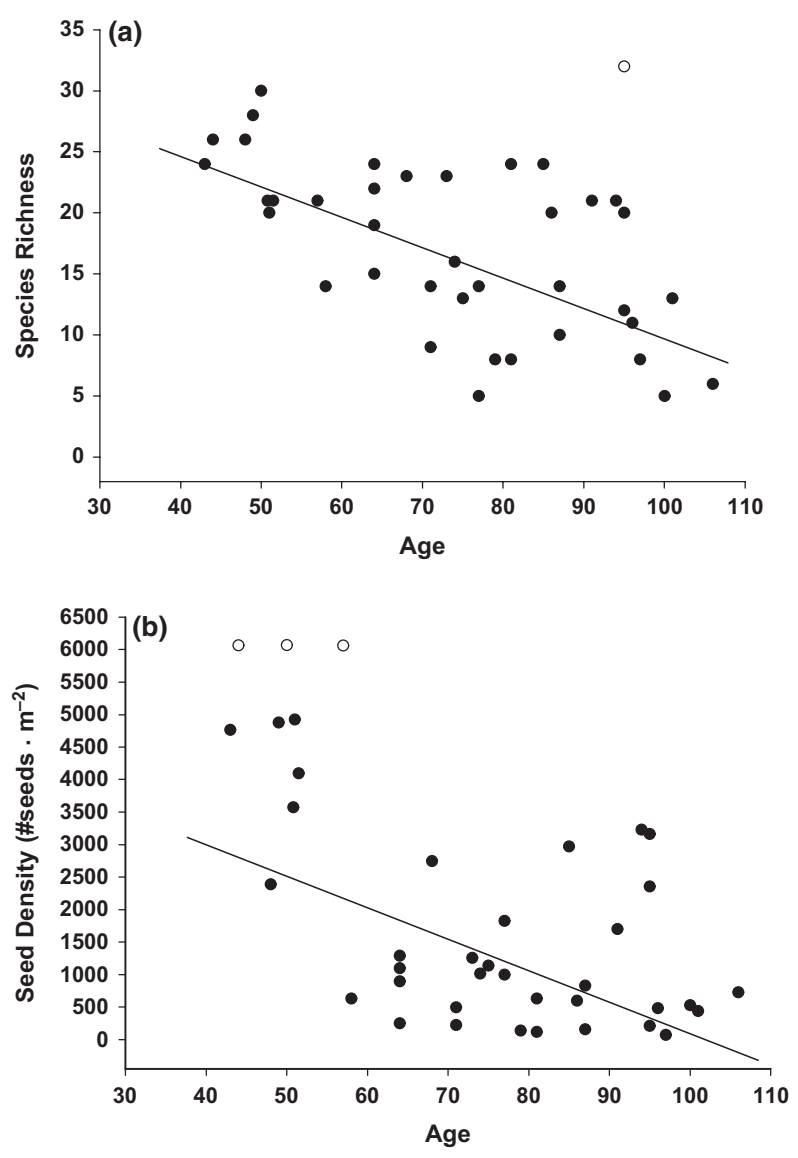

Fig. 1. Relationship between seed bank (a) species richness $\left(Y_{\text {richness }}=-0.23 X_{\text {age }}+34.53 ; P<0.0001 ; r^{2}=0.38\right)$ and $(\mathbf{b})$ abundance $\left(Y_{\text {density }}=-45.24 X_{\text {age }}+5033 ; P<0.0001 ; r^{2}=0.28\right)$ and site age in 39 sites ranging in age between 43 and $106 \mathrm{yr}$ post-establishment. Open circles represent outlier sites excluded from analyses due to their excessive influence as assessed with Cook's D.

Overall, seed bank community composition differed among groups of different ages (Table la), and sites in the oldest group tended to be different from the two youngest groups $(P=0.006$ and 0.013 , respectively); however no individual pair-wise differences were significant following the Holm-Bonferroni correction. $\beta$-diversity, as measured by the test of multivariate dispersion, significantly increased over time, with the youngest sites exhibiting significantly lower dispersion relative to the much higher dispersion found in the older sites (Table 1b, Fig. 2a, Appendix S1b). Inter-site variation in soil moisture potential did contribute to the observed differences among seed bank community composition; however, relative density, our measure of overstorey tree density, did not (Table la).

In contrast, although composition of the herbaceous layer was affected by soil moisture potential, species composition was similar across all age classes and was unaffected by relative density (Table la). More importantly,
Table 1. Results of (a) permutational MANOVA and (b) permutational test of multivariate dispersion. The two analyses used a matrix containing the Raup-Crick dissimilarities of all pairs of samples.

\begin{tabular}{|c|c|c|c|c|c|c|}
\hline \multirow[t]{2}{*}{ Source } & \multicolumn{3}{|c|}{ Seed bank } & \multicolumn{3}{|c|}{ Herbaceous layer } \\
\hline & $d f$ & $F$ & $P$ & $d f$ & $F$ & $P$ \\
\hline \multicolumn{7}{|l|}{ (a) } \\
\hline Age $_{\text {bins }}$ & 4 & 12.866 & 0.003 & 4 & 3.470 & 0.168 \\
\hline Soil moisture potential & 1 & 14.805 & 0.011 & 1 & 19.262 & 0.009 \\
\hline Relative density & 1 & 1.174 & 0.454 & 1 & -1.978 & 0.831 \\
\hline Age $_{\text {bins }} \times$ Soil moisture & 4 & 0.477 & 0.640 & 4 & 6.165 & 0.053 \\
\hline $\begin{array}{l}\text { Age }_{\text {bins }} \times \text { Relative } \\
\text { density }\end{array}$ & 4 & 1.585 & 0.354 & 4 & 2.646 & 0.217 \\
\hline Error & 24 & & & 24 & & \\
\hline \multicolumn{7}{|l|}{ (b) } \\
\hline Age $_{\text {bins }}$ & 4 & 4.020 & 0.011 & 4 & 5.063 & 0.003 \\
\hline Error & 34 & & & 34 & & \\
\hline Pair-wise differences* & & $40-51<$ & $95+$ & & $\begin{array}{l}80-94> \\
95+\end{array}$ & 69-79, \\
\hline
\end{tabular}

*Significant pair-wise differences corrected for excessive Type I error rate using the Holm-Bonferroni adjustment.

differences in $\beta$-diversity were inconsistent (Table $1 \mathrm{~b}$ ) or non-existent (Appendix Slb), exhibiting no tendency towards increasing or decreasing dispersion among age classes, and the oldest sites were as tightly clustered as the youngest (Fig. 2b).

Finally, seed bank communities exhibited significant nestedness along the chronosequence, indicating that species composition at older sites were a non-random subset of the species pool found at younger sites $\left(\mathrm{NODF}_{\text {sites }}=40.52, P=0.003\right)$. In contrast, the herbaceous layer did not exhibit a nested pattern $\left(\mathrm{NODF}_{\text {sites }}=34.08\right.$, $P=0.167)$.

\section{Discussion}

Our results show unequivocally that seed bank community dynamics differ profoundly from those of the extant herbaceous community. Specifically, only the seed bank displayed a consistent decline in $\alpha$-diversity (i.e. richness) and abundance across a gradient of increasingly older sites. More importantly, only seed bank communities displayed increasing nestedness over time, yet simultaneously demonstrated divergent compositional trajectories, whereby older sites were increasingly dissimilar, not only from younger sites, but also from each other. These seemingly contrasting temporal dynamics in two $\beta$-diversity metrics across sites that otherwise experienced no significant disturbance since establishment, are similar in canopy composition and do not differ predictably in overstorey density or soil moisture suggest the importance of both deterministic (i.e. differential seed longevities) and stochastic (e.g. failed germination, propagule colonization) processes in structuring seed bank communities. 

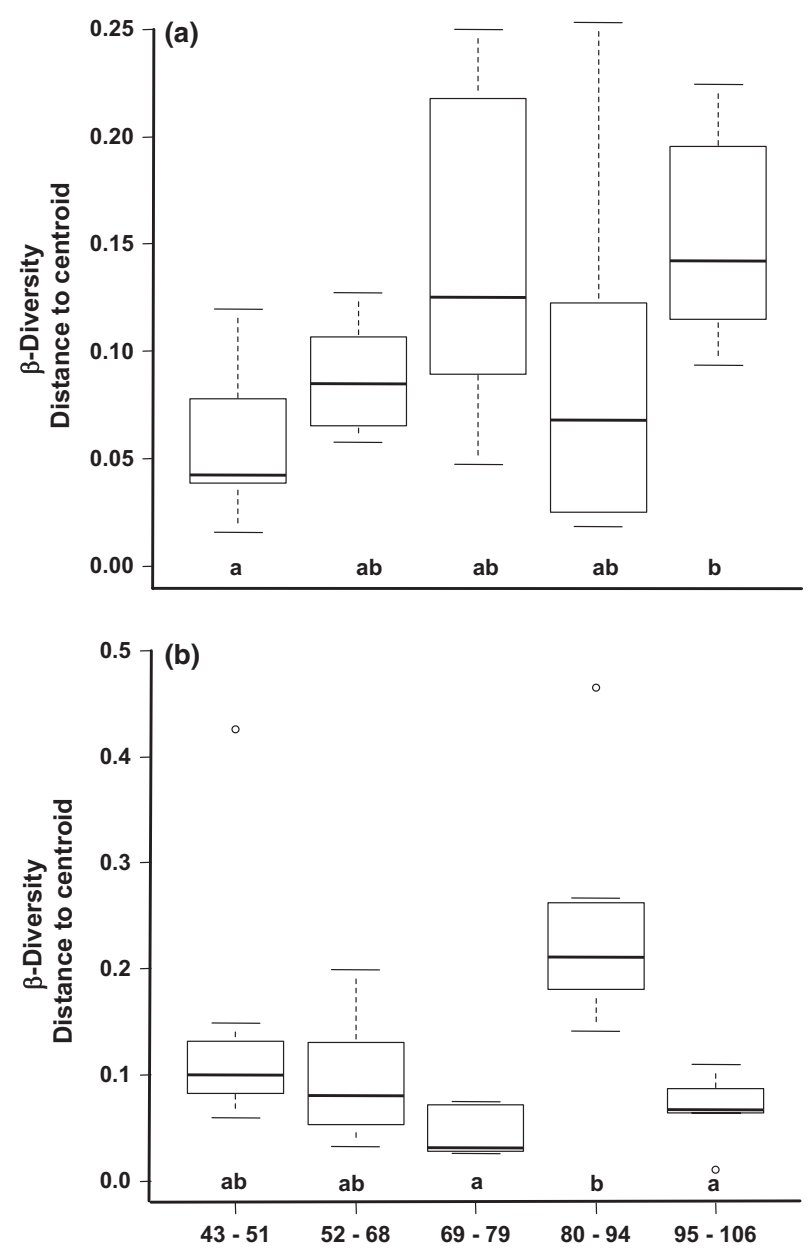

Fig. 2. Heterogeneity in community composition (i.e. within-group RaupCrick dissimilarity $\left.\left[\beta_{\mathrm{RC}}\right]\right)$ for the (a) seed bank and (b) herbaceous layer communities over time. Box-plots show the median (dark line), 25th and 75th percentiles (area within the box), 10th and 90th percentiles (whiskers) and outliers (open circles), with significant differences among year means indicated with lowercase letters along the $x$-axis.

\section{Deterministic disassembly of seed banks}

Zavaleta et al. (2009) define community trajectories that display progressive and non-random declines in both species richness and abundance as being in a state of disassembly. While disassembly has primarily been applied to shifts governed by anthropogenic drivers (e.g. habitat conversion, species invasions), we suggest this definition is applicable to seed banks in the decades following disturbance. Specifically, following the high influx of species into the seed bank in the initial years after disturbance, the community begins a trajectory of sequential exhaustion over the course of the next several decades, driven primarily by differential seed persistence (Van Calster et al. 2008). Our findings reinforce numerous studies documenting declines in seed bank richness and abundance following canopy closure and forest maturation (reviewed in Bossuyt $\&$ Hermy 2001).

In addition to undergoing shifts in richness and abundance, seed bank assemblages at older sites were shown in nestedness analyses to represent a subset of the species at younger sites. Nested species assemblage patterns are predicted in communities ordered by extinction (reviewed in Wright et al. 1998). To our knowledge, our results are among the first to quantitatively test the prediction that as seed banks disassemble, species composition converges on a restricted set of species possessing the longest seed longevities (see also Van Calster et al. 2008; Plue et al. 2010a). Plue et al. (2010a) confirmed this ordered extinction prediction by finding a significant correlation between the rank order of species nestedness and seed longevity data. Unfortunately, equivalent data on seed longevities are lacking for most North American plant species, thus precluding a similar test with our data. Nevertheless, examination of the packed species matrix reveals that species and genera possessing relatively long-term seed banks dominated throughout the chronosequence. These taxa are, in rank order: $R$. allegheniensis, L. multiflora, Carex spp., V. mackloskeyi, D. compressa, Polygonum cilinode, and Juncus spp. (Rowe 1983; Peterson \& Carson 1996; Leckie et al. 2000; Kleyer et al. 2008; Ristau et al. 2011). Seeds of Betula spp. were found across most stands (fifth in rank order in packed matrix), but their ubiquity is likely a combination of moderate seed longevity (2-5 yr; Hille Ris Lambers et al. 2005), abundant seed production and long dispersal (Matlack 1989).

\section{Stochasticity in seed banks}

Although older sites had fewer seeds of less species representing a restricted subset of species found in younger sites, seed banks among older sites were not increasingly homogeneous. On the contrary, we found $\beta$-diversity, as measured by within-group dispersion, was lowest among young stands and highest among the oldest stands. Indeed, our results may underestimate the magnitude of $\beta$-diversity as many unidentifiable sedge species were collapsed to genus level. Regional surveys (e.g. Anacker \& Kirschbaum 2006) have found $\geq 25$ species of Carex occur locally, yet are quite patchy in their distribution, a factor that would only increase $\beta$-diversity.

Our findings are in stark contrast to Plue et al. (2010a), who found reduced $\beta$-diversity at older stands within a forest area in Germany. We suspect part of this discrepancy is explained by differences between the studies' spatial and temporal scales (see model below). Plue et al. (2010a) intensively sampled seed banks in small (0.01 ha) replicate forest plots in 40-250-yr-old stands located within a 
640-ha forest reserve with relatively homogeneous soil conditions. While our temporal scale is more limited (43$106 \mathrm{yr}$ old), our sampling design is considerably more dispersed, with sampling occurring throughout much larger (0.42-ha) areas, each of which was widely distributed across a $240-\mathrm{km}$ swath of forest land. Such differences in spatial scales may influence the findings, given that at relatively local scales, a strongly shared species pool and similar biotic and abiotic conditions may constrain possible disassembly trajectories. In contrast, our study spanning a broad spatial scale may be more representative of realized $\beta$-diversity as slight inter-site variation in propagule colonization and mortality events and ecological drift may yield different trajectories. Furthermore, local biotic or abiotic factors may act stochastically provided they affect seed colonization or extinction similarly across species (e.g. generalist fungal pathogens, soil moisture). Indeed, we found variability in soil moisture also explained some variability in seed bank composition. Such variations in soil moisture are known to alter species' seed extinction probabilities, with seeds in sites at either end of the moisture continuum typically experiencing shorter longevities (Ashton et al. 1998; Leckie et al. 2000; Blaney \& Kotanen 2001).

Our results documenting both nestedness and increasing divergence appear contradictory, particularly as some have argued that communities exhibiting high nestedness should similarly exhibit low $\beta$-diversity as community composition narrows towards a restricted set of species (Wright \& Reeves 1992). Nestedness and divergence, however, measure different aspects of $\beta$-diversity. The former is a specific measure of directional turnover due to ordered species losses across assemblages, whereas divergence more broadly measures overall variation in species composition among assemblages (Baeten et al. 2012). Hence, sites may exhibit nestedness if species losses over time are consistent across sites, divergence if species turnover varies across sites, or both (see below; Samuels \& Drake 1997).

We suggest that although seed bank trajectories possess deterministic inertia towards nestedness due to ordered seed extinctions, stochastic factors may simultaneously increase community divergence over time. We suggest the observed community variation in seed banks of older sites occurred through at least three phenomena. First, a few species possessing persistent seed banks were sporadically found in older sites, yet not in the herbaceous layer (e.g. Ajuga reptans, Cardamine pratensis, Erechtites hieraciifolia). Other taxa lacking long-term persistence were similarly absent from the herbaceous layer, yet were occasionally found at older sites (e.g. Fragaria virginiana, Rhus spp.). Finally, some species were present in both herbaceous layer and seed bank samples at older sites (e.g. Gaultheria procumbens, Sassafras albidum). These patterns suggest that inter-site variation early in seed bank establishment or extinction of persistent seeds, long-distance colonization events of both transient and persistent seeds and in situ colonization via local reproductive events all play a role in differentiating communities.

\section{Temporal shifts in $\alpha$ - and $\beta$-diversity}

Our data document a pattern of decreasing $\alpha$-diversity (i.e. richness) and increasing $\beta$-diversity (i.e. divergence) as forests mature. These results partially support the conclusions of two recent reviews of seed bank dynamics in temperate forests (Bossuyt \& Hermy 2001; Plue et al. 2010b). Specifically, our results confirm seed banks in younger stands are dominated by light-demanding, early successional species (e.g. R. allegheniensis, L. multiflora; Appendix S2) and, ca. $50 \mathrm{yr}$ post-disturbance, begin to become increasingly depauperate. However, we found seed bank assemblages diverged, rather than converged, at older sites.

We propose an integrated conceptual model that depicts temporal dynamics in seed bank $\alpha$ - and $\beta$-diversity (Fig. 3). The model builds on those of Falińska (1999) and Van Calster et al. (2008), describing temporal shifts in local seed bank richness and abundance, and links these changes in $\alpha$-diversity to concomitant changes in $\beta$-diversity, as proposed by Chase \& Myers (2011). Furthermore, the model incorporates the role of disturbance regimes as a homogenizing force in seed banks throughout forest development (Plue et al. 2010b; Chase et al. 2011). Our model predicts that following stand-replacing disturbance events, individual sites will be characterized by increased seed bank richness and abundance and low among-site variability in young stands ( $<40 \mathrm{yr}$ old), as influx into the seed bank, particularly for common, light-demanding, early successional species is enhanced. As forests pass into a relatively stable period where trees are actively growing and disturbance is rare (40-100 yr old), local seed banks will grow increasingly depauperate through deterministic extinctions of resident species, yet stochastic differences among sites in the timing and pattern of species losses and gains will greatly influence species composition and increase divergence. Finally, as forest stands age further and transition into late-successional stands $(100+\mathrm{yr}$ old), canopy disturbance (e.g. gaps) will again stimulate understorey plant growth, reproduction and recruitment, potentially replenishing the seed bank and reducing $\beta$-diversity (Mladenoff 1990; Leckie et al. 2000; Plue et al. 2010b). Further, our model predicts the degree of change in $\alpha$ - and $\beta$-diversity at older sites varies as a function of disturbance severity. Large and/or frequent disturbances may dramatically alter propagule inputs into soil seed banks through increased dominance and reproduction of common early-successional species and intensified competitive environments, increased physiological stress and outright 


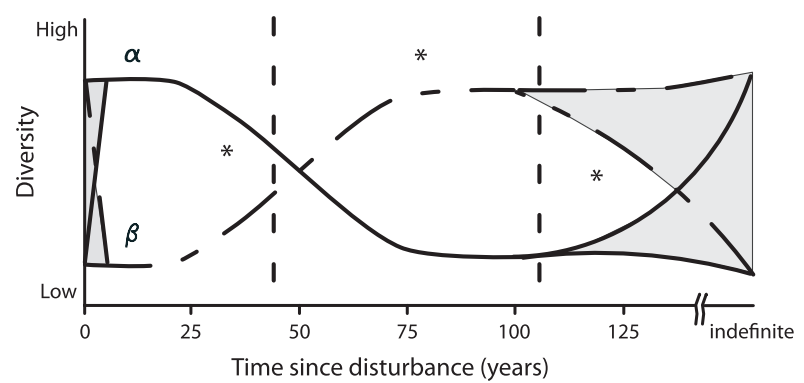

Fig. 3. Conceptual model of the relationship between seed bank $\alpha$ - (solid line) and $\beta$ - (dashed-dotted line) diversity over time. In the initial years following disturbance as well as when stands transition into latesuccessional stands $(>100 \mathrm{yr})$, the degree of change in both $\alpha$ - and $\beta$-diversity varies depending on disturbance frequency, size and severity (grey areas). Sites in our study span the region bounded by the two vertical dotted lines (43-106 yr old). Bossuyt \& Hermy's (2001) review documenting low $\beta$-diversity in European seed bank records is based on a majority (29/36) of records from forests $\leq 40$ or $\geq 100 \mathrm{yr}$ old. Asterisks represent the hypothetical position of stands with differing $\beta$-diversity reported in Plue et al. (2010a).

mortality on forest herbs, thereby homogenizing seed banks (Meier et al. 1995; Hyatt \& Casper 2000). In contrast, less severe or patchy disturbances may promote influx of propagules into the seed bank, moderating the decline of or even augmenting $\beta$-diversity (Plue et al. 2010b).

\section{Conclusion}

While this and other studies show a deterministic loss of species over time, we contest the conventional belief that forest herbs rarely form seed banks, and thus, seed banks are relatively unimportant to forest herb diversity recovery following disturbance (reviewed in Pickett $\delta$ McDonnell 1989). The spatio-temporal shifts in seed bank diversity described by our model support a growing number of studies that document several forest herbaceous species in seed banks of mature forests, albeit at low densities (e.g. Bossuyt \& Hermy 2001; Godefroid et al. 2006; Royo et al. 2010; Plue et al. 2012). Therefore, we suggest that even in forests that are passively managed to retain old-growth, we predict seed banks play a role in maintaining plant diversity. At the other end of the continuum, our findings show actively managed forests with relatively short rotations (e.g. $100 \mathrm{yr}$ ) can retain high native species diversity, as our model suggests recurring disturbances enhance propagule recruitment into seed banks and thus help maintain $\alpha$-diversity. Finally, our empirical findings and our prediction of increased $\beta$-diversity over time most likely represent the mosaic of heterogeneity in seed bank establishment, depletion and replenishment that almost certainly occur across the landscape. We suggest that this heterogeneity helps promote diversity in understorey communities that represent the bulk of the vascular species richness in many temperate forests (Gilliam 2007).

We propose that a pattern of waxing and waning $\beta$-diversity may be common in assemblages, such as seed banks, which are largely homogenous when established through disturbance events and then diverge through differential species residence times and inter-site differences in mortality and colonization events. Although evidence for temporal and spatial differences in $\beta$-diversity remains scarce, this prediction has support from observational and experimental work in other systems, including communities of stream fish (Strange et al. 1993), experimental pond macroinvertebrates (Chase 2007; Jeffries 2011) and restored wetland plant (Matthews \& Spyreas 2010) communities. Findings across disparate systems suggest both deterministic and stochastic processes simultaneously govern post-disturbance spatial and temporal turnover in species assemblages.

\section{Acknowledgements}

This work was supported by the Pennsylvania Department of Conservation and Natural Resources, Bureau of Forestry and the U.S. Department of Agriculture, Forest Service Northern Research Station. We thank Martin Dovčiak, Jan Plue, Matthew D. Trager, Mark Vellend and three anonymous reviewers for comments on this manuscript, and J. Stanovick for statistical consultation and review.

\section{References}

Adler, P.B., HilleRisLambers, J. \& Levine, J.M. 2007. A niche for neutrality. Ecology Letters 10: 95-104.

Allison, L.E. 1965. Soil organic matter. In: Black, C.A., Evans, D. D., White, J.L., Ensminger, L.E. \& Clark, F.E. (eds.) Methods of soil analysis, part 1. pp. 1367-1389. American Society of Agronomy, Madison, WI, US.

Almeida-Neto, M., Guimaraes, P., Guimaraes, P.R. Jr, Loyola, R. D. \& Ulrich, W. 2008. A consistent metric for nestedness analysis in ecological systems: reconciling concept and measurement. Oikos 117: 1227-1239.

Anacker, B.L. \& Kirschbaum, C.D. 2006. Vascular flora of the Kinzua Quality Deer Cooperative, northwestern Pennsylvania, USA. Bartonia 63: 11-28.

Anderson, M.J. 2001. A new method for non-parametric multivariate analysis of variance. Austral Ecology 26: 32-46.

Anderson, M.J., Ellingsen, K.E. \& McArdle, B.H. 2006. Multivariate dispersions as a measure of beta diversity. Ecology Letters 9: 683-693.

Anderson, M.J., Crist, T.O., Chase, J.M., Vellend, M., Inouye, B. D., Freestone, A.L., Sanders, N.J., Cornell, H.V., Comita, L.S. \& Davies, K.F. 2011. Navigating the multiple meanings of $\beta$ 
diversity: a roadmap for the practicing ecologist. Ecology Letters 14: 19-28.

Ashton, P.M.S., Harris, P.G. \& Thadani, R. 1998. Soil seed bank dynamics in relation to topographic position of a mixeddeciduous forest in southern New England, USA. Forest Ecology and Management 111: 15-22.

Baeten, L., Hermy, M., Van Daele, S. \& Verheyen, K. 2010. Unexpected understorey community development after 30 years in ancient and post-agricultural forests. Journal of Ecology 98: 1447-1453.

Baeten, L., Vangansbeke, P., Hermy, M., Peterken, G., Vanhuyse, K. \& Verheyen, K. 2012. Distinguishing between turnover and nestedness in the quantification of biotic homogenization. Biodiversity and Conservation 21: 1399-1409.

Blaney, C.S. \& Kotanen, P.M. 2001. Effects of fungal pathogens on seeds of native and exotic plants: a test using congeneric pairs. Journal of Applied Ecology 38: 1104-1113.

Bossuyt, B. \& Hermy, M. 2001. Influence of land use history on seed banks in European temperate forest ecosystems: a review. Ecography 24: 225-238.

Bruelheide, H., Böhnke, M., Both, S., Fang, T., Assmann, T., Baruffol, M., Bauhus, J., Buscot, F., Chen, X.Y. \& Ding, B.Y. 2011. Community assembly during secondary forest succession in a Chinese subtropical forest. Ecological Monographs 81: $25-41$.

Chase, J.M. 2007. Drought mediates the importance of stochastic community assembly. Proceedings of the National Academy of Sciences, USA 104: 17430-17434.

Chase, J.M. \& Myers, J.A. 201 1. Disentangling the importance of ecological niches from stochastic processes across scales. Philosophical Transactions of the Royal Society B: Biological Sciences 366: 2351-2363.

Chase, J.M., Kraft, N.J.B., Smith, K.G., Vellend, M. \& Inouye, B.D. 2011. Using null models to disentangle variation in community dissimilarity from variation in $\beta$ diversity. Ecosphere 2: article 24. URL: http://www.esajournals.org/doi/pdf/10.1890/ES1000117.1 [Ecological Society of America].

Chesson, P. 2000. Mechanisms of maintenance of species diversity. Annual Review of Ecology and Systematics 31: 343-366.

Christensen, N.L. \& Peet, R.K. 1984. Convergence during secondary forest succession. Journal of Ecology 72: 25-36.

Clements, F.E. 1916. Plant succession: an analysis of the development of vegetation. Carnegie Institute Publication No. 242, Washington, DC, US.

Connell, J.H. \& Slatyer, R.O. 1977. Mechanisms of succession in natural communities and their role in community stability and organization. American Naturalist 111: 1119-1 144.

Day, P.R. 1965. Particle fractionation and particle size analysis. In: Black, C.A., Evans, D.D., White, J.L., Ensminger, L.E. \& Clark, F.E. (eds.) Methods of soil analysis, agronomy, 9. pp. 545556. American Society of Agronomy, Madison, WI, US.

Decocq, G., Valentin, B., Toussaint, B., Hendoux, F., Saguez, R. \& Bardat, J. 2004. Soil seed bank composition and diversity in a managed temperate deciduous forest. Biodiversity and Conservation 13: 2485-2509.
Dovčiak, M. \& Halpern, C.B. 2010. Positive diversity-stability relationships in forest herb populations during four decades of community assembly. Ecology Letters 13: 1300-1309.

Dupuy, J.M. \& Chazdon, R.L. 1998. Long-term effects of forest regrowth and selective logging on the seed bank of tropical forests in NE Costa Rica. Biotropica 30: 223-237.

Falińska, K. 1999. Seed bank dynamics in abandoned meadows during a 20 year period in the Białowieża National Park. Journal of Ecology 87: 461-475.

Gilliam, F.S. 2007. The ecological significance of the herbaceous layer in temperate forest ecosystems. BioScience 57: 845-858.

Gleason, H.A. 1927. Further views on the succession concept. Ecology 8: 299-326.

Godefroid, S., Phartyal, S.S. \& Koedam, N. 2006. Depth distribution and composition of seed banks under different tree layers in a managed temperate forest ecosystem. Acta Oecologica 29: 283-292.

Granstrom, A. 1987. Seed viability of fourteen species during five years of storage in a forest soil. Journal of Ecology 72: 321-331.

Halpern, C.B. 1989. Early successional patterns of forest species: interactions of life history traits and disturbance. Ecology 70: 704-720.

Hille Ris Lambers, J., Clark, J.S. \& Lavine, M. 2005. Implications of seed banking for recruitment of southern Appalachian woody species. Ecology 86: 85-95.

Hubbell, S.P. 2001. The unified neutral theory of biodiversity and biogeography. Princeton University Press, Princeton, NJ, US.

Hutchings, M.J. 1986. Plant population biology. In: Moore, P.D. \& Chapman, S.B. (eds.) Methods in plant ecology. pp. 377-435. Blackwell, Oxford, UK.

Hyatt, L.A. \& Casper, B.B. 2000. Seed bank formation during early secondary succession in a temperate deciduous forest. Journal of Ecology 88: 516-527.

Jankowska-Błaszczuk, M., Kwiatkowska, A.J., Panufnik, D. \& Tanner, E. 1998. The size and diversity of the soil seed banks and the light requirements of the species in sunny and shady natural communities of the Białowieża Primeval Forest. Plant Ecology 136: 105-118.

Jeffries, M. 2011. The temporal dynamics of temporary pond macroinvertebrate communities over a 10-year period. Hydrobiologia 661: 391-405.

Kjellsson, G. 1992. Seed banks in Danish deciduous forests: species composition, seed influx and distribution pattern in soil. Ecography 15: 86-100.

Kleyer, M., Bekker, R.M., Knevel, I.C., Bakker, J.P., Thompson, K., Sonnenschein, M., Poschlod, P., Van Groenendael, J.M., Klimes, L., Klimesova, J., Klotz, S., Rusch, G.M., Hermy, M., Adriaens, D., Boedeltje, G., Bossuyt, B., Dannemann, A., Endels, P., Gotzenberger, L., Hodgson, J.G., Jackel, A.-K., Kuhn, I., Kunzmann, D., Ozinga, W.A., Romermann, C., Stadler, M., Schlegelmilch, J., Steendam, H.J., Tackenberg, O., Wilmann, B., Cornelissen, J.H.C., Eriksson, O., Garnier, E. \& Peco, B. 2008. The LEDA Traitbase: a database of life history traits of the Northwest European flora. Journal of Ecology 96: 1266-1274. 
Leck, M.A., Thomas, P.V. \& Simpson, R.L. 1989. Ecology of soil seed banks. I462 p. Academic Press, Inc., San Diego, CA, US.

Leckie, S., Vellend, M., Bell, G., Waterway, M.J. \& Lechowicz, M.J. 2000. The seed bank in an old-growth, temperate deciduous forest. Canadian Journal of Botany 78: 181-192.

Livingston, R.B. \& Allessio, M.L. 1968. Buried viable seed in successional field and forest stands, Harvard Forest, Massachusetts. Bulletin of the Torrey Botanical Club 95: 58-69.

Marquis, D.A. 1975a. The Allegheny hardwood forests of Pennsylvania. p.32. USDA Forest Service, Broomall, PA, US.

Marquis, D.A. 1975b. Seed storage and germination under northern hardwood forests. Canadian Journal of Forest Research 5: 478-484.

Marquis, D.A. 1979. Shelterwood cutting in Allegheny hardwoods. Journal of Forestry 77: 140-144.

Matlack, G.R. 1989. Secondary dispersal of seed across snow in Betula lenta, a gap-colonizing tree species. Journal of Ecology 77: 853-869.

Matthews, J.W. \& Spyreas, G. 2010. Convergence and divergence in plant community trajectories as a framework for monitoring wetland restoration progress. Journal of Applied Ecology 47: 1128-1136.

McCune, B. \& Grace, J.B. 2002. Analysis of ecological communities. MjM Software Design, Gleneden Beach, OR, US.

Meier, A.J., Bratton, S.P. \& Duffy, D.C. 1995. Possible ecological mechanisms for loss of vernal-herb diversity in logged eastern deciduous forests. Ecological Applications 5: 935-946.

Mladenoff, D.J. 1990. The relationship of the soil seed bank and understory vegetation in old-growth northern hardwoodhemlock treefall gaps. Canadian Journal of Botany 68: 27142721 .

Nakagoshi, N. 1985. Buried viable seeds in temperate forests. In: White, J. (ed.) The population structure of vegetation. pp. 551570. Dr W. Junk, Dordrecht, NL, US.

Oksanen, J., Blanchet, F.G., Kindt, R., Legendre, P., Minchin, R. B., O'Hara, G.L., Simpson, G.L., Solymos, P., Stevens, M.H. H. \& Wagner, H. 2012. Vegan: Community Ecology Package. $R$ Package Version 2.0-5. Available at: http://cran.r-project.org/ web/packages/vegan/index.html.

Oosting, H.J. 1942. An ecological analysis of the plant communities of Piedmont, North Carolina. American Midland Naturalist 28: 1-126.

Peterson, C.J. \& Carson, W.P. 1996. Generalizing forest regeneration models: the dependence of propagule availability on disturbance history and stand size. Canadian Journal of Forest Research 26: 45-52.

Pickett, S.T.A. \& McDonnell, M.J. 1989. Seed bank dynamics in temperate deciduous forest. In: Garwood, N.C., Leck, M.A., Parker, V.T. \& Simpson, R.L. (eds.) Ecology of soil seed banks. pp. 123-147. Academic Press, New York, NY, US.

Plue, J., Van Gils, B., Peppler-Lisbach, C., De Schrijver, A., Verheyen, K. \& Hermy, M. 2010a. Seed-bank convergence under different tree species during forest development. Perspectives in Plant Ecology, Evolution and Systematics 12: $211-$ 218.
Plue, J., Verheyen, K., Van Calster, H., Marage, D., Thompson, K., Kalamees, R., Jankowska-Błaszczuk, M., Bossuyt, B. \& Hermy, M. 2010b. Seed banks of temperate deciduous forests during secondary succession. Journal of Vegetation Science 21: 965-978.

Plue, J., Thompson, K., Verheyen, K. \& Hermy, M. 2012. Seed banking in ancient forest species: why total sampled area really matters. Seed Science Research 22: 123-133.

Purves, D.W. \& Turnbull, L.A. 2010. Different but equal: the implausible assumption at the heart of neutral theory. Journal of Animal Ecology 79: 1215-1225.

Raup, D.M. \& Crick, R.E. 1979. Measurement of faunal similarity in paleontology. Journal of Paleontology 53: 1213-1227.

Ristau, T.E., Stoleson, S.H., Horsley, S.B. \& deCalesta, D.S. 2011. Ten-year response of the herbaceous layer to an operational herbicide-shelterwood treatment in a northern hardwood forest. Forest Ecology and Management 262: 970-979.

Roberts, M.R. 2004. Response of the herbaceous layer to natural disturbance in North American forests. Canadian Journal of Botany 82: 1273-1283.

Roberts, M.R. \& Gilliam, F.S. 2003. Response of the herbaceous layer to disturbance in eastern forests. In: Gilliam, F.S. \& Roberts, M.R. (eds.) The herbaceous layer in forests of eastern North America. pp. 301-320. Oxford University Press, New York, NY, US.

Rosenzweig, M.L. 1995. Species diversity in space and time. Cambridge University Press, Cambridge, UK.

Rowe, J.S. 1983. Concepts of fire effects on plant individuals and species. In: Wein, R.W. \& MacLean, D.A. (eds.) The role of fire in northern circumpolar ecosystems. pp. 135-154. John Wiley \& Sons, New York, NY, US.

Royo, A.A., Collins, R., Adams, M.B., Kirschbaum, C. \& Carson, W.P. 2010. Pervasive interactions between ungulate browsers and disturbance regimes promote temperate forest herbaceous diversity. Ecology 91: 93-105.

Royo, A.A., Scalley, T.H., Moya, S. \& Scatena, F.N. 2011. Nonarborescent vegetation trajectories following repeated hurricane disturbance: ephemeral versus enduring responses. Ecosphere 2: article 77. URL: http://www.esajournals.org/doi/ pdf/10.1890/ES1 1-00118.1 [Ecological Society of America].

Samuels, C.L. \& Drake, J.A. 1997. Divergent perspectives on community convergence. Trends in Ecology e Evolution 12:427-432.

Saxton, K.E. \& Rawls, W.J. 2006. Soil water characteristic estimates by texture and organic matter for hydrologic solutions. Soil Science Society of America Journal 70: 1569-1578.

Schiffman, P.M. \& Johnson, W.C. 1992. Sparse buried seed bank in a southern Appalachian oak forest: implications for succession. American Midland Naturalist 127: 258-267.

Smith, D.M. 1986. The practice of silviculture. John Wiley \& Sons, New York, NY, US.

Stout, S.L. \& Nyland, R.D. 1986. Role of species composition in relative density measurement in Allegheny hardwoods. Canadian Journal of Forest Research 16: 574-579.

Strange, E.M., Moyle, P.B. \& Foin, T.C. 1993. Interactions between stochastic and deterministic processes in stream fish community assembly. Environmental Biology of Fishes 36: 1-15. 
Suding, K.N., Gross, K.L. \& Houseman, G.R. 2004. Alternative states and positive feedbacks in restoration ecology. Trends in Ecology $\theta$ Evolution 19: 46-53.

Thompson, K. \& Grime, J.P. 1979. Seasonal variation in the seed banks of herbaceous species in ten contrasting habitats. Journal of Ecology 67: 893-921.

Thompson, K., Bakker, J.P. \& Bekker, R.M. 1997. The soil seed banks of north west Europe: methodology, density and longevity. Cambridge University Press, Cambridge, UK.

Ulrich, W., Almeida-Neto, M. \& Gotelli, N.J. 2009. A consumer's guide to nestedness analysis. Oikos 118: 3-17.

USDA NRCS. 2012. The plants database. National Plant Data Center, Baton Rouge, LA, US, Available at: http://plants.usda. gov/ (Accessed: 2 February 2012).

Van Calster, H., Chevalier, R., Wyngene, B., Archaux, F., Verheyen, K. \& Hermy, M. 2008. Long term seed bank dynamics in a temperate forest under conversion from coppice with standards to high forest management. Applied Vegetation Science 11: 251-260.

Vellend, M., Verheyen, K., Flinn, K.M., Jacquemyn, H., Kolb, A., Van Calster, H., Peterken, G., Graae, B., Bellemare, J. \& Honnay, O. 2007. Homogenization of forest plant communities and weakening of species-environment relationships via agricultural land use. Journal of Ecology 95: 565-573.
Whitney, G.G. 1990. The history and status of the hemlockhardwood forests of the Allegheny Plateau. Journal of Ecology 78: 443-458.

Wright, D.H. \& Reeves, J.H. 1992. On the meaning and measurement of nestedness of species assemblages. Oecologia 92: 416-428.

Wright, D.H., Patterson, B.D., Mikkelson, G.M., Cutler, A. \& Atmar, W. 1998. A comparative analysis of nested subset patterns of species composition. Oecologia 113: 1-20.

Zavaleta, E., Pasari, J., Moore, J., Hernandez, D., Suttle, K.B. \& Wilmers, C.C. 2009. Ecosystem responses to community disassembly. Annals of the New York Academy of Sciences 1162: $311-333$.

\section{Supporting Information}

Additional supporting information may be found in the online version of this article:

Appendix S1. Results of PERMANOVA and PERMDISP on data binned into 15-yr intervals.

Appendix S2. Herbaceous layer and seed bank composition in a chronosequence of 39 stands ranging in age from 43 to 106 yr post-establishment. 


\section{Online Appendices}

Table S1. Results of permutational MANOVA (A) and permutational test of multivariate dispersion (B) on data binned into 15 year intervals. The two analyses used the partitioned a matrix containing the Raup-Crick dissimilarities of all pairs of samples. Significant pair-wise differences shown are corrected for excessive Type I error rate using the Holm-Bonferroni adjustment.

\begin{tabular}{|c|c|c|c|c|c|c|}
\hline \multirow[b]{2}{*}{ Source } & \multicolumn{3}{|c|}{ Seed Bank } & \multicolumn{3}{|c|}{ Herbaceous Layer } \\
\hline & d.f. & $\mathbf{F}$ & $\mathbf{P}$ & d.f. & $\mathbf{F}$ & $\mathbf{P}$ \\
\hline Age $_{\text {bins }}$ & 4 & 9.377 & 0.009 & 4 & 0.840 & 0.511 \\
\hline Soil Moisture Potential & 1 & 21.363 & 0.005 & 1 & 11.335 & 0.042 \\
\hline Relative Density & 1 & 4.671 & 0.113 & 1 & -4.574 & 0.965 \\
\hline Age $_{\text {bins }} \times$ Soil Moisture & 4 & 0.405 & 0.659 & 4 & 3.639 & 0.132 \\
\hline Age $_{\text {bins }} \times$ Relative Density & 4 & 2.393 & 0.181 & 4 & 1.432 & 0.362 \\
\hline Error & 24 & & & 24 & & \\
\hline
\end{tabular}

b: Permutational Test of

Dispersion

\begin{tabular}{lrrrrrrrr}
\hline & \multicolumn{3}{c}{ Seed Bank } & & \multicolumn{3}{c}{ Herbaceous Layer } \\
Source & d.f. & $\mathbf{F}$ & $\mathbf{P}$ & & d.f. & $\mathbf{F}$ & P \\
\hline Age $_{\text {bins }}$ & 4 & 3.487 & 0.014 & & 4 & 0.596 & 0.674 \\
Error & 34 & & & & 34 & & \\
\hline Pairwise differences* & \multicolumn{4}{c}{$40-54,55-59<100+$} & & & \\
\hline
\end{tabular}


Table S2. Herbaceous layer and seed bank composition in a chronosequence of 39 stands ranging in age from 43 - 106 years post-establishment. Stands were binned into quintiles of increasing stand age (i.e., Agebins). Values represent the frequency of stands within each Agebin in which a given species was present. $\mathrm{N}=$ the number of stands within each bin. Species nomenclature follows USDA Plants Database (USDA NRCS 2012).

\begin{tabular}{|c|c|c|c|c|c|c|}
\hline Scientific Name & Survey & $\begin{array}{c}\text { Age }_{\text {bin } 1} 1 \\
(43-51) \\
N=8\end{array}$ & $\begin{array}{c}\text { Age }_{\text {bin }} 2 \\
(52-68) \\
N=7\end{array}$ & $\begin{array}{c}\text { Age }_{\text {bin }} 3 \\
(69-79) \\
N=8\end{array}$ & $\begin{array}{c}\mathrm{Age}_{\mathrm{bin}} 4 \\
(80-94) \\
\mathrm{N}=8\end{array}$ & $\begin{array}{c}\mathrm{Age}_{\mathrm{bin}} 5 \\
(95-106) \\
\mathrm{N}=8\end{array}$ \\
\hline \multirow[t]{2}{*}{ Acer spp. } & Herbaceous Layer & - & - & - & - & - \\
\hline & Seed Bank & 0.125 & - & - & - & - \\
\hline \multirow[t]{2}{*}{ Acer pensylvanicum spp. } & Herbaceous Layer & 0.625 & 0.714 & 0.625 & 0.500 & 0.500 \\
\hline & Seed Bank & - & - & - & - & - \\
\hline \multirow[t]{2}{*}{ Acer rubrum spp. } & Herbaceous Layer & 0.500 & 0.286 & 0.125 & 0.375 & 0.500 \\
\hline & Seed Bank & 1.000 & 1.000 & 1.000 & 1.000 & 1.000 \\
\hline \multirow[t]{2}{*}{ Acer saccharum } & Herbaceous Layer & 1.000 & 0.714 & 0.500 & 0.500 & 0.375 \\
\hline & Seed Bank & - & - & - & - & - \\
\hline \multirow[t]{2}{*}{ Acer spicatum } & Herbaceous Layer & - & 0.143 & - & - & - \\
\hline & Seed Bank & - & - & - & - & - \\
\hline \multirow[t]{2}{*}{ Actaea pachypoda } & Herbaceous Layer & - & 0.143 & - & 0.125 & - \\
\hline & Seed Bank & - & - & - & - & - \\
\hline \multirow[t]{2}{*}{ Actaea rubra } & Herbaceous Layer & 0.125 & - & - & - & - \\
\hline & Seed Bank & - & - & - & - & - \\
\hline \multirow[t]{2}{*}{ Adiantum pedatum } & Herbaceous Layer & - & - & - & 0.125 & - \\
\hline & Seed Bank & - & - & - & - & - \\
\hline \multirow[t]{2}{*}{ Ajuga reptans } & Herbaceous Layer & 0.750 & 0.143 & - & 0.250 & 0.125 \\
\hline & Seed Bank & - & - & - & - & - \\
\hline \multirow[t]{2}{*}{ Alliaria petiolata } & Herbaceous Layer & 0.125 & - & - & 0.125 & - \\
\hline & Seed Bank & - & - & - & - & - \\
\hline \multirow[t]{2}{*}{ Allium cernuum } & Herbaceous Layer & 0.125 & - & - & - & - \\
\hline & Seed Bank & - & - & - & - & - \\
\hline \multirow[t]{2}{*}{ Allium tricoccum } & Herbaceous Layer & 0.250 & - & 0.125 & 0.125 & - \\
\hline & Seed Bank & - & - & - & - & - \\
\hline \multirow[t]{2}{*}{ Amelanchier arborea } & Herbaceous Layer & 1.000 & 1.000 & 1.000 & 0.875 & 1.000 \\
\hline & Seed Bank & - & - & - & - & - \\
\hline \multirow[t]{2}{*}{ Amelanchier spp. } & Herbaceous Layer & 0.125 & - & - & - & 0.125 \\
\hline & Seed Bank & - & - & - & - & - \\
\hline \multirow[t]{2}{*}{ Anaphalis spp. } & Herbaceous Layer & - & - & - & - & - \\
\hline & Seed Bank & 0.125 & - & - & - & - \\
\hline \multirow[t]{2}{*}{ Anthoxanthum spp. } & Herbaceous Layer & - & - & - & - & - \\
\hline & Seed Bank & - & - & 0.125 & - & - \\
\hline Anthoxanthum odoratum & Herbaceous Layer & - & - & - & - & - \\
\hline
\end{tabular}


Aquilegia canadensis

Aralia spp

Aralia nudicaulis

Arisaema triphyllum

Asclepias syriaca

Asplenium platyneuron

Aster spp.

Athyrium filix-femina

Berberis thunbergii

Betula alleghaniensis

Betula spp.

Betula lenta

Betula papyrifera var. cordifolia

Bidens spp.

Boehmeria cylindrica

Botrychium spp.

Brachyelytrum erectum

Brassica spp.

Cardamine diphylla

Cardamine pratensis

Carex communis

Carex debilis

Carex hitchcockiana

Carex hystericina

Carex intumescens
Seed Bank

Herbaceous Layer Seed Bank

Herbaceous Layer Seed Bank

Herbaceous Layer Seed Bank

Herbaceous Layer Seed Bank

0.875

0.125

Herbaceous Layer Seed Bank

0.250

Herbaceous Layer Seed Bank

Herbaceous Layer Seed Bank

Herbaceous Layer Seed Bank

Herbaceous Layer Seed Bank

Herbaceous Layer Seed Bank

Herbaceous Layer Seed Bank

Herbaceous Layer Seed Bank

Herbaceous Layer Seed Bank

Herbaceous Layer Seed Bank

Herbaceous Layer Seed Bank

Herbaceous Layer Seed Bank

Herbaceous Layer Seed Bank

Herbaceous Layer Seed Bank

Herbaceous Layer Seed Bank

Herbaceous Layer Seed Bank

Herbaceous Layer Seed Bank

Herbaceous Layer Seed Bank

Herbaceous Layer Seed Bank

Herbaceous Layer Seed Bank

Herbaceous Layer

0.125

-

0.500

0.125

0.125

0.125

0.250

0.375

0.125

0.125

1.000

0.125

0.375

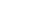

$-$

0.500

0.125

1.000

0.625

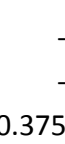

0.375
0.286

0.125

0.250

0.143

0.571

0.143

0.375

0.125

.

0.571

0.125

0.286

0.125

0.125

0.857

0.750

0.875

0.714

0.143

0.143

0.143

0.143

0.714

1.000

0.125

0.750

0.143

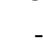

$$
0.429
$$

0.375

0.250

0.625

1.000

0.286

0.250

0.143

143
0.125

0.250

0.125

0.250

0.125<smiles>C1CCC1</smiles>

$-$

-

0.375
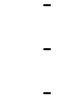$$
\begin{array}{r}
.125 \\
-
\end{array}
$$

$0.750 \quad 0.750$

$1.000 \quad 0.750$

-

$$
-
$$$$
-
$$

0.125

$\begin{array}{rr}- & \\ 0.625 & 0.250\end{array}$

$0.750 \quad 0.500$

-

0.375

0.125

0.250

0.375

0.125

0.125

1.000

0.375

0.625

0.250

0.125

0.250

0.125 


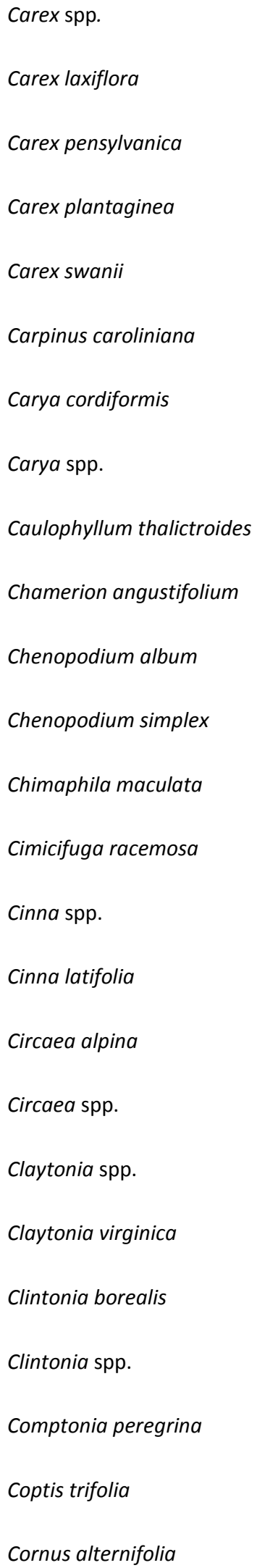

Seed Bank
Herbaceous Layer
Seed Bank
Herbaceous Layer
Seed Bank

Herbaceous Layer Seed Bank

Herbaceous Layer Seed Bank

Herbaceous Layer Seed Bank

Herbaceous Layer Seed Bank

Herbaceous Layer Seed Bank

Herbaceous Layer Seed Bank

Herbaceous Layer Seed Bank

Herbaceous Layer Seed Bank

Herbaceous Layer Seed Bank

Herbaceous Layer Seed Bank

Herbaceous Layer Seed Bank

Herbaceous Layer Seed Bank

Herbaceous Layer Seed Bank

Herbaceous Layer Seed Bank

Herbaceous Layer Seed Bank

Herbaceous Layer Seed Bank

Herbaceous Layer Seed Bank

Herbaceous Layer Seed Bank

Herbaceous Layer Seed Bank

Herbaceous Layer Seed Bank

Herbaceous Layer Seed Bank

Herbaceous Layer Seed Bank

Herbaceous Layer

\begin{tabular}{|c|c|c|c|c|}
\hline- & - & - & - & 0.125 \\
\hline 1.000 & 1.000 & 1.000 & 1.000 & 0.750 \\
\hline 0.625 & 0.429 & 0.125 & 0.250 & 0.125 \\
\hline- & - & - & - & - \\
\hline- & - & - & 0.125 & - \\
\hline- & - & 0.250 & - & 0.125 \\
\hline- & - & 0.125 & - & - \\
\hline 0.125 & - & - & - & 0.125 \\
\hline- & - & - & - & - \\
\hline 0.875 & 0.571 & 0.625 & 0.625 & 0.250 \\
\hline 0.125 & - & 0.125 & - & - \\
\hline 0.375 & 0.286 & - & - & 0.125 \\
\hline- & - & - & - & - \\
\hline 0.125 & - & - & - & - \\
\hline- & - & - & - & - \\
\hline 0.250 & 0.571 & 0.125 & 0.500 & 0.250 \\
\hline- & - & - & - & - \\
\hline 0.250 & - & - & 0.125 & - \\
\hline- & - & - & - & - \\
\hline- & - & - & - & - \\
\hline- & - & 0.125 & - & - \\
\hline- & - & - & - & - \\
\hline- & - & 0.125 & - & - \\
\hline- & - & - & - & - \\
\hline- & 0.143 & - & - & - \\
\hline- & - & - & 0.125 & - \\
\hline- & - & - & - & - \\
\hline- & - & - & 0.125 & - \\
\hline- & - & - & - & - \\
\hline 0.250 & 0.286 & 0.250 & 0.375 & 0.125 \\
\hline- & - & - & - & - \\
\hline- & - & - & 0.125 & - \\
\hline- & 0.143 & - & - & - \\
\hline 0.125 & 0.143 & - & 0.250 & - \\
\hline - & - & - & - & - \\
\hline 0.125 & - & - & - & - \\
\hline- & - & - & - & - \\
\hline 0.125 & - & - & - & 0.125 \\
\hline - & - & - & - & - \\
\hline
\end{tabular}

0.750

0.143

0.250

0.125

0.250

0.125

0.125

0.143

0.125

0.125

0.286

0.143

0.143

0.250
0.125

0.750

-

125

0.125

0.250

.125

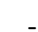

.250

-

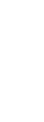




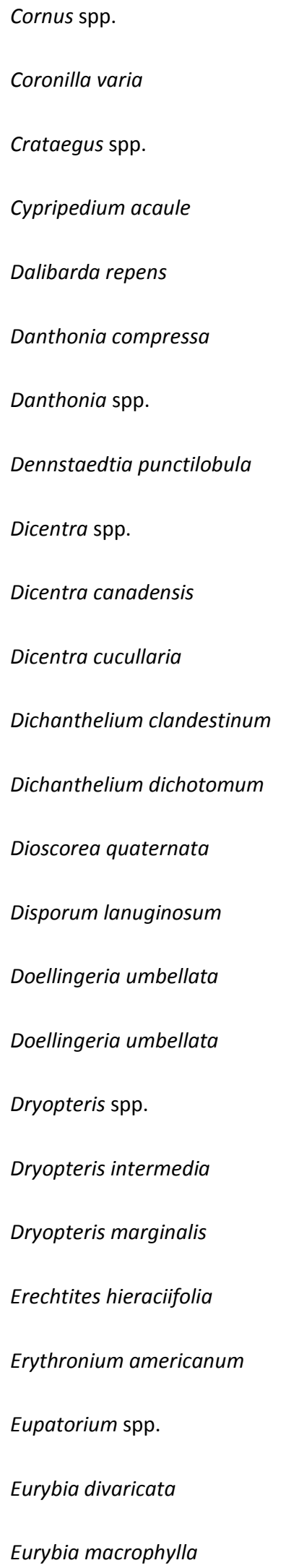

Seed Bank

Herbaceous Layer

0.125

0.286

Seed Bank

Herbaceous Layer Seed Bank

Herbaceous Layer Seed Bank

Herbaceous Layer Seed Bank

Herbaceous Layer Seed Bank

Herbaceous Layer Seed Bank

Herbaceous Layer Seed Bank

Herbaceous Layer Seed Bank

Herbaceous Layer Seed Bank

Herbaceous Layer Seed Bank

Herbaceous Layer Seed Bank

Herbaceous Layer Seed Bank

Herbaceous Layer Seed Bank

Herbaceous Layer Seed Bank

Herbaceous Layer Seed Bank

Herbaceous Layer 0.143

0.375

0.857

0.286

- 0.143

0.125

0.500

0.125

-

0.143

0.625

0.571

0.500

0.286

1.000

0.857

0.429

0.750

0.571

0.875

1.000

0.500

0.500

0.375

$\begin{array}{lll}0.250 & 0.375 & 0.250\end{array}$

$0.500 \quad 0.875$

0.375

$0.375 \quad 0.625$

0.500

1.000

0.750

1.000

0.125

$0.125 \quad 0.250$

$$
\text { - - }
$$

0.125

0.625

1.000

0.125

0.500

0.250

0.125

0.714

0.125

0.500

$0.250 \quad 0.500$

0.250

0.125

0.571

0.250

0.250

0.250

0.125 Seed Bank

Herbaceous Layer Seed Bank

Herbaceous Layer Seed Bank

Herbaceous Layer Seed Bank

Herbaceous Layer Seed Bank

Herbaceous Layer Seed Bank

Herbaceous Layer Seed Bank

Herbaceous Layer Seed Bank

Herbaceous Layer Seed Bank

Herbaceous Layer

0.143

0.125

0.375

0.143

0.125

0.429

1.000

0.857

0.429

0.750

0.250

0.750

0.125

0.125

0.250

0.250

0.125

0.875

0.143

0.125

0.250

0.250

0.143

0.125

0.125

0.625

0.714

0.375

0.750

0.375

0.125

0.125

0.125

0.714

0.250

0.125 
Fagus grandifolia

Festuca spp.

Fragaria virginiana

Fraxinus americana

Galium asprellum

Galium circaezans

Galium spp.

Galium lanceolatum

Galium odoratum

Galium triflorum

Gaultheria procumbens

Gaylussacia baccata

Glyceria melicaria

Glyceria spp.

Hamamelis virginiana

Hepatica nobilis var. acuta

Hesperis matronalis

Hieracium aurantiacum

Hieracium spp.

Hieracium venosum

Huperzia lucidula

Hydrophyllum virginianum

Hypericum spp.

Hypericum punctatum

Ilex montana
Seed Bank

Herbaceous Layer Seed Bank

Herbaceous Layer Seed Bank

Herbaceous Layer Seed Bank

Herbaceous Layer Seed Bank

Herbaceous Layer Seed Bank

Herbaceous Layer Seed Bank

Herbaceous Layer Seed Bank

Herbaceous Layer Seed Bank

Herbaceous Layer Seed Bank

Herbaceous Layer Seed Bank

Herbaceous Layer Seed Bank

Herbaceous Layer Seed Bank

Herbaceous Layer Seed Bank

Herbaceous Layer Seed Bank

Herbaceous Layer Seed Bank

Herbaceous Layer Seed Bank

Herbaceous Layer Seed Bank

Herbaceous Layer Seed Bank

Herbaceous Layer Seed Bank

Herbaceous Layer Seed Bank

Herbaceous Layer Seed Bank

Herbaceous Layer Seed Bank

Herbaceous Layer Seed Bank

Herbaceous Layer Seed Bank

Herbaceous Layer
0.875

0.429

0.750

0.625

0.625

0.125

0.375

0.143

0.750

0.42

0.500

0.125

0.125

0.500

0.250

0.125

0.250

0.125

0.125

0.250

0.143

0.375

0.143

0.143

0.250

0.250

0.125

0.125

0.125

0.125

0.714

0.571

0.375

0.500

0.500

0.250

0.125

0.125

0.125

0.125

0.250

0.143

0.125

0.714

0.375

0.250

0.500

0.125

0.125

0.125

0.125

0.143

0.250

0.125

0.375

0.143

0.143

0.143

0.125

0.125

0.125

0.125

0.125

0.125

0.125

0.143

0.125

0.125 


\begin{tabular}{|c|c|c|c|c|c|c|}
\hline & Seed Bank & 0.250 & 0.286 & 0.125 & 0.500 & 0.125 \\
\hline \multirow[t]{2}{*}{ Impatiens capensis } & Herbaceous Layer & 0.250 & - & 0.125 & 0.125 & - \\
\hline & Seed Bank & - & - & - & - & - \\
\hline \multirow[t]{2}{*}{ Impatiens spp. } & Herbaceous Layer & - & 0.286 & 0.125 & 0.125 & 0.250 \\
\hline & Seed Bank & 0.250 & - & - & 0.375 & - \\
\hline \multirow[t]{2}{*}{ Juncus spp. } & Herbaceous Layer & - & - & - & - & - \\
\hline & Seed Bank & 0.875 & 0.286 & 0.500 & 0.375 & 0.125 \\
\hline \multirow[t]{2}{*}{ Kalmia latifolia spp. } & Herbaceous Layer & - & 0.286 & 0.125 & 0.250 & 0.375 \\
\hline & Seed Bank & - & - & - & - & - \\
\hline \multirow[t]{2}{*}{ Laportea canadensis } & Herbaceous Layer & 0.125 & - & 0.250 & 0.250 & 0.125 \\
\hline & Seed Bank & - & - & - & - & - \\
\hline \multirow[t]{2}{*}{ Lindera benzoin } & Herbaceous Layer & 0.125 & - & - & - & - \\
\hline & Seed Bank & - & - & - & - & - \\
\hline \multirow[t]{2}{*}{ Liriodendron tulipifera } & Herbaceous Layer & - & 0.429 & 0.125 & - & - \\
\hline & Seed Bank & - & 0.429 & 0.250 & 0.125 & - \\
\hline \multirow[t]{2}{*}{ Lobelia spp. } & Herbaceous Layer & 0.125 & 0.429 & - & - & - \\
\hline & Seed Bank & - & - & - & - & - \\
\hline \multirow[t]{2}{*}{ Luzula multiflora } & Herbaceous Layer & 1.000 & 0.857 & 0.750 & 0.875 & 0.875 \\
\hline & Seed Bank & - & - & - & - & - \\
\hline \multirow[t]{2}{*}{ Lycopodium annotinum } & Herbaceous Layer & 0.125 & - & - & - & - \\
\hline & Seed Bank & - & - & - & - & - \\
\hline \multirow[t]{2}{*}{ Lycopodium clavatum } & Herbaceous Layer & 0.125 & 0.143 & - & - & - \\
\hline & Seed Bank & - & - & - & - & - \\
\hline \multirow[t]{2}{*}{ Lycopodium digitatum } & Herbaceous Layer & 0.250 & 0.286 & - & 0.250 & 0.125 \\
\hline & Seed Bank & - & - & - & - & - \\
\hline \multirow[t]{2}{*}{ Lycopodium obscurum } & Herbaceous Layer & 0.375 & 0.571 & 0.500 & 0.625 & 0.500 \\
\hline & Seed Bank & - & - & - & - & - \\
\hline \multirow[t]{2}{*}{ Lycopus spp. } & Herbaceous Layer & 0.250 & 0.143 & 0.125 & 0.125 & 0.125 \\
\hline & Seed Bank & 0.125 & - & - & - & - \\
\hline \multirow[t]{2}{*}{ Lycopus uniflorus } & Herbaceous Layer & - & 0.143 & 0.125 & - & - \\
\hline & Seed Bank & - & - & - & - & - \\
\hline \multirow[t]{2}{*}{ Lysimachia spp. } & Herbaceous Layer & 0.125 & 0.571 & - & 0.250 & 0.250 \\
\hline & Seed Bank & - & - & - & - & - \\
\hline \multirow[t]{2}{*}{ Lysimachia quadrifolia } & Herbaceous Layer & 0.125 & 0.571 & - & 0.250 & 0.125 \\
\hline & Seed Bank & 0.125 & 0.286 & 0.250 & 0.125 & 0.250 \\
\hline \multirow[t]{2}{*}{ Magnolia acuminata } & Herbaceous Layer & 0.125 & 0.857 & 0.500 & 0.250 & 0.375 \\
\hline & Seed Bank & - & - & - & - & - \\
\hline \multirow[t]{2}{*}{ Maianthemum canadense } & Herbaceous Layer & 0.875 & 1.000 & 0.875 & 0.750 & 0.625 \\
\hline & Seed Bank & 0.125 & 0.286 & 0.250 & 0.250 & 0.125 \\
\hline \multirow[t]{2}{*}{ Maianthemum racemosum } & Herbaceous Layer & 0.125 & 0.714 & 0.250 & 0.500 & 0.250 \\
\hline & Seed Bank & - & - & - & - & - \\
\hline \multirow[t]{2}{*}{ Malus sylvestris } & Herbaceous Layer & - & - & - & 0.125 & - \\
\hline & Seed Bank & - & - & - & - & - \\
\hline Medeola virginiana & Herbaceous Layer & 0.750 & 1.000 & 0.875 & 0.875 & 0.875 \\
\hline & Seed Bank & - & - & - & - & - \\
\hline Mentha spp. & Herbaceous Layer & - & 0.143 & - & 0.125 & - \\
\hline & Seed Bank & - & - & - & - & - \\
\hline Microstegium vimineum & Herbaceous Layer & - & 0.143 & - & 0.125 & - \\
\hline & Seed Bank & - & 0.286 & - & 0.125 & - \\
\hline Mitchella repens & Herbaceous Layer & 0.750 & 0.571 & 0.875 & 0.750 & 0.750 \\
\hline
\end{tabular}


Mitella diphylla

Monotropa uniflora

Nyssa sylvatica

Oclemena acuminata

Onoclea sensibilis

Osmunda cinnamomea

Osmunda claytoniana

Osmunda spp.

Ostrya virginiana

Oxalis spp.

Oxalis montana

Oxalis stricta

Panax trifolius

Panicum spp.

Parthenocissus quinquefolia

Phytolacca americana

Picea glauca

Pilea pumila

Pinus strobus

Platanthera spp.

Platanthera macrophylla

Platanthera orbiculata

Podophyllum peltatum

Pogonia spp.

Polemonium vanbruntiae
Seed Bank

Herbaceous Layer Seed Bank

Herbaceous Layer Seed Bank

Herbaceous Layer Seed Bank

Herbaceous Layer Seed Bank

Herbaceous Layer Seed Bank

Herbaceous Layer Seed Bank

Herbaceous Layer Seed Bank

Herbaceous Layer Seed Bank

Herbaceous Layer Seed Bank

Herbaceous Layer Seed Bank

Herbaceous Layer Seed Bank

Herbaceous Layer Seed Bank

Herbaceous Layer Seed Bank

Herbaceous Layer Seed Bank

Herbaceous Layer Seed Bank

Herbaceous Layer Seed Bank

Herbaceous Layer Seed Bank

Herbaceous Layer Seed Bank

Herbaceous Layer Seed Bank Herbaceous Layer Seed Bank

Herbaceous Layer Seed Bank

Herbaceous Layer Seed Bank

Herbaceous Layer Seed Bank

Herbaceous Layer Seed Bank Herbaceous Layer
0.125

0.125

0.375

0.125

0.143

0.143

0.143

0.286

0.250

0.250

-

0.375

0.500

0.625

0.375

0.125

0.125

0.250

-

0.125

0.571

0.125

$-$

0.125

0.571

0.125

0.500

0.125

0.125

0.250

0.125

0.125

0.125

0.875

0.571

0.375

0.500

0.250

0.125

0.250

0.250

0.250

0.375

0.375

0.143

0.375

0.125

0.286

-

0.125

0.125

0.375

0.250

0.375

0.125

0.125

0.286

-

0.375

0.143

0.143

0.125
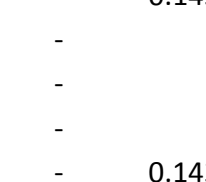

0.125

0.143

0.143

0.250

0.125

0.375

0.500

0.125

0.125

0.143

0.250

0.429

0.500

0.250

0.125

0.125 
Polygala paucifolia

Polygonatum biflorum

Polygonatum spp.

Polygonatum pubescens

Polygonum caespitosum

Polygonum cilinode

Polygonum spp.

Polygonum persicaria

Polystichum acrostichoides

Populus grandidentata

Populus spp.

Populus tremuloides

Potentilla canadensis

Potentilla spp.

Potentilla simplex

Prenanthes altissima

Prenanthes spp.

Prenanthes trifoliolata

Prunus pensylvanica

Prunus serotina

Prunus virginiana

Pteridium aquilinum

Pteridium spp.

Pyrola spp.

Quercus alba
Seed Bank

Herbaceous Layer Seed Bank

Herbaceous Layer Seed Bank

Herbaceous Layer Seed Bank

Herbaceous Layer Seed Bank

Herbaceous Layer Seed Bank

Herbaceous Layer Seed Bank

0.375

0.143

0.143

Herbaceous Layer Seed Bank

Herbaceous Layer Seed Bank

Herbaceous Layer Seed Bank

Herbaceous Layer Seed Bank

Herbaceous Layer Seed Bank

Herbaceous Layer Seed Bank

Herbaceous Layer Seed Bank

Herbaceous Layer Seed Bank

Herbaceous Layer Seed Bank

Herbaceous Layer Seed Bank

Herbaceous Layer Seed Bank

Herbaceous Layer Seed Bank

Herbaceous Layer Seed Bank

Herbaceous Layer Seed Bank

Herbaceous Layer Seed Bank

Herbaceous Layer Seed Bank

Herbaceous Layer Seed Bank

Herbaceous Layer Seed Bank

Herbaceous Layer

0.429

0.143

0.125

0.286

0.286

0.750

0.143

0.143

0.375

0.286

0.143

0.125

0.500

0.286

0.250

0.143

0.375

0.571

0.125

0.375

0.143

0.250

0.125

0.750

1.000

1.000

0.375

0.143

1.000

0.143

0.250

0.143

0.571

0.143

0.143

0.250

0.857
0.625

0.250

0.250

0.375

0.500

0.125

0.250

0.250

0.250

$\begin{array}{lll}0.375 & 0.250 & 0.125\end{array}$

0.250

0.125

0.250

0.250

0.250

1.000

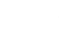

0.125

0.250

0.125

0.125

0.125

0.125

0.125

0.250

0.125

0.250

0.375

0.125

1.000

0.375

1.000

0.250

-

0.125

0.125

0.375

0.375

0.375 


\begin{tabular}{|c|c|c|c|c|c|c|}
\hline \multirow[t]{2}{*}{ Quercus coccinea } & Herbaceous Layer & 0.125 & 0.143 & 0.125 & 0.500 & 0.375 \\
\hline & Seed Bank & - & - & - & - & \\
\hline \multirow[t]{2}{*}{ Quercus prinus } & Herbaceous Layer & - & 0.429 & 0.375 & 0.500 & 0.375 \\
\hline & Seed Bank & - & - & - & - & \\
\hline \multirow[t]{2}{*}{ Quercus rubra } & Herbaceous Layer & 0.625 & 0.857 & 0.750 & 0.750 & 0.750 \\
\hline & Seed Bank & - & - & - & - & \\
\hline \multirow[t]{2}{*}{ Ranunculus abortivus } & Herbaceous Layer & 0.125 & - & - & 0.125 & 0.125 \\
\hline & Seed Bank & - & - & - & - & \\
\hline \multirow[t]{2}{*}{ Ranunculus allegheniensis } & Herbaceous Layer & - & - & 0.125 & - & 0.125 \\
\hline & Seed Bank & - & - & - & - & \\
\hline \multirow[t]{2}{*}{ Ranunculus spp. } & Herbaceous Layer & 0.250 & 0.286 & - & - & 0.125 \\
\hline & Seed Bank & - & - & - & - & \\
\hline \multirow[t]{2}{*}{ Rhododendron periclymenoides } & Herbaceous Layer & 0.125 & 0.143 & 0.250 & 0.250 & 0.375 \\
\hline & Seed Bank & - & - & - & - & \\
\hline \multirow[t]{2}{*}{ Rhusspp. } & Herbaceous Layer & 0.875 & - & 0.125 & 0.125 & 0.500 \\
\hline & Seed Bank & - & - & - & - & \\
\hline \multirow[t]{2}{*}{ Ribes cynosbati } & Herbaceous Layer & - & - & - & - & 0.125 \\
\hline & Seed Bank & - & - & - & - & - \\
\hline \multirow[t]{2}{*}{ Ribes spp. } & Herbaceous Layer & 0.125 & - & - & - & \\
\hline & Seed Bank & - & - & - & - & \\
\hline \multirow[t]{2}{*}{ Rosa multiflora } & Herbaceous Layer & 0.125 & 0.571 & - & - & 0.125 \\
\hline & Seed Bank & - & - & - & - & - \\
\hline \multirow[t]{2}{*}{ Rubus allegheniensis } & Herbaceous Layer & 0.500 & 0.857 & 0.500 & 0.375 & 0.750 \\
\hline & Seed Bank & 1.000 & 0.857 & 1.000 & 0.875 & 1.000 \\
\hline \multirow[t]{2}{*}{ Rubus flagellaris } & Herbaceous Layer & - & - & - & - & \\
\hline & Seed Bank & 0.125 & - & - & - & \\
\hline \multirow[t]{2}{*}{ Rubus hispidus } & Herbaceous Layer & 0.375 & - & 0.250 & - & 0.125 \\
\hline & Seed Bank & 0.125 & 0.286 & 0.375 & 0.125 & 0.250 \\
\hline \multirow[t]{2}{*}{ Rubus idaeus } & Herbaceous Layer & - & - & 0.375 & - & 0.125 \\
\hline & Seed Bank & 0.250 & - & - & - & . \\
\hline \multirow[t]{2}{*}{ Rubus occidentalis } & Herbaceous Layer & - & - & - & - & \\
\hline & Seed Bank & - & - & - & 0.125 & 0.125 \\
\hline \multirow[t]{2}{*}{ Rubus odoratus } & Herbaceous Layer & - & - & - & - & - \\
\hline & Seed Bank & - & - & - & 0.125 & - \\
\hline \multirow[t]{2}{*}{ Rubusspp. } & Herbaceous Layer & - & - & - & - & 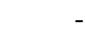 \\
\hline & Seed Bank & 0.125 & - & - & - & 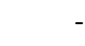 \\
\hline \multirow[t]{2}{*}{ Rumex acetosella } & Herbaceous Layer & - & - & - & - & \\
\hline & Seed Bank & 0.500 & 0.143 & - & - & - \\
\hline \multirow[t]{2}{*}{ Rumex obtusifolius } & Herbaceous Layer & - & - & 0.125 & - & - \\
\hline & Seed Bank & - & - & - & - & . \\
\hline \multirow[t]{2}{*}{ Sambucus spp. } & Herbaceous Layer & 0.375 & 0.143 & 0.375 & 0.125 & 0.125 \\
\hline & Seed Bank & 0.500 & 0.143 & 0.500 & 0.250 & 0.125 \\
\hline Sambucus racemosa & Herbaceous Layer & - & - & 0.250 & - & - \\
\hline & Seed Bank & 0.250 & 0.143 & - & 0.125 & \\
\hline Sassafras albidum & Herbaceous Layer & - & 0.857 & - & 0.375 & 0.500 \\
\hline & Seed Bank & - & 0.286 & 0.125 & 0.500 & - \\
\hline Schizachyrium scoparium & Herbaceous Layer & - & - & - & 0.125 & \\
\hline & Seed Bank & - & - & - & - & 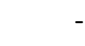 \\
\hline Scirpus cyperinus & Herbaceous Layer & - & - & 0.125 & - & \\
\hline
\end{tabular}


Smilax herbacea

Smilax L.

Smilax rotundifolia

Smilax tamnoides

Solanum carolinense

Solidago altissima

Solidago caesia

Solidago spp.

Solidago rugosa

Sorbus americana

Stellaria spp.

Streptopus amplexifolius

Streptopus lanceolatus var. roseus

Taraxacum officinale

Thelypteris noveboracensis

Thelypteris simulata

Tiarella cordifolia

Tilia americana

Toxicodendron radicans

Trientalis borealis

Trillium erectum

Trillium spp.

Trillium undulatum

Tsuga canadensis

Tussilago farfara
Seed Bank

Herbaceous Layer Seed Bank

Herbaceous Layer Seed Bank

Herbaceous Layer Seed Bank

Herbaceous Layer Seed Bank

Herbaceous Layer Seed Bank

Herbaceous Layer Seed Bank

Herbaceous Layer Seed Bank

Herbaceous Layer Seed Bank

Herbaceous Layer Seed Bank Herbaceous Layer Seed Bank

Herbaceous Layer Seed Bank

Herbaceous Layer Seed Bank

Herbaceous Layer Seed Bank

Herbaceous Layer Seed Bank

Herbaceous Layer Seed Bank

Herbaceous Layer Seed Bank

Herbaceous Layer Seed Bank

Herbaceous Layer Seed Bank

Herbaceous Layer Seed Bank

Herbaceous Layer Seed Bank

Herbaceous Layer Seed Bank

Herbaceous Layer Seed Bank

Herbaceous Layer Seed Bank

Herbaceous Layer Seed Bank Herbaceous Layer
0.125

0.286

0.125

0.125

0.143

0.125

0.125

0.125

0.286

0.250

0.125

0.375

0.125

0.429

0.250

0.375

0.125

0.375

0.125

0.143

0.625

1.000

0.250

0.250

0.375

0.125

0.125

0.125

0.125

0.143

0.125

0.143

0.125

0.125

0.143

0.125

0.875

0.857

0.375

0.625

0.750

0.125

0.143

0.125

0.143

0.375

0.143

0.125

0.250

0.125

0.125

0.143

0.125

0.250

0.143

0.625

0.714

0.625

0.500

0.750

0.375

0.571

0.500

0.125

0.375

0.875

0.286

0.750

0.375

0.500

0.125

0.125

0.250

0.250

0.375

0.375

0.125 


\begin{tabular}{|c|c|c|c|c|c|c|}
\hline \multirow[t]{2}{*}{ Urtica dioica } & Herbaceous Layer & - & - & - & - & - \\
\hline & Seed Bank & - & - & - & - & 0.125 \\
\hline \multirow[t]{2}{*}{ Uvularia perfoliata } & Herbaceous Layer & 0.125 & 0.714 & - & - & - \\
\hline & Seed Bank & - & - & - & - & - \\
\hline \multirow[t]{2}{*}{ Uvularia sessilifolia } & Herbaceous Layer & 0.875 & 1.000 & 0.625 & 1.000 & 0.875 \\
\hline & Seed Bank & 0.250 & - & - & 0.125 & - \\
\hline \multirow[t]{2}{*}{ Vaccinium angustifolium } & Herbaceous Layer & 0.125 & 0.857 & 0.500 & 0.500 & 0.500 \\
\hline & Seed Bank & - & - & - & - & - \\
\hline \multirow[t]{2}{*}{ Vaccinium spp. } & Herbaceous Layer & 0.125 & 0.286 & 0.250 & 0.250 & 0.375 \\
\hline & Seed Bank & - & - & 0.125 & - & - \\
\hline \multirow[t]{2}{*}{ Vaccinium pallidum } & Herbaceous Layer & - & 0.143 & - & - & 0.125 \\
\hline & Seed Bank & - & - & - & - & - \\
\hline \multirow[t]{2}{*}{ Vaccinium stamineum } & Herbaceous Layer & - & 0.286 & 0.125 & 0.375 & 0.125 \\
\hline & Seed Bank & - & - & - & - & - \\
\hline \multirow[t]{2}{*}{ Veratrum spp. } & Herbaceous Layer & 0.375 & - & - & - & - \\
\hline & Seed Bank & - & - & - & - & - \\
\hline \multirow[t]{2}{*}{ Verbascum thapsus } & Herbaceous Layer & - & - & - & - & - \\
\hline & Seed Bank & 0.375 & - & 0.125 & - & - \\
\hline \multirow[t]{2}{*}{ Veronica spp. } & Herbaceous Layer & - & - & - & 0.125 & - \\
\hline & Seed Bank & - & - & - & 0.125 & - \\
\hline \multirow[t]{2}{*}{ Veronica officinalis } & Herbaceous Layer & - & - & - & - & 0.125 \\
\hline & Seed Bank & 0.625 & - & - & 0.125 & 0.125 \\
\hline \multirow[t]{2}{*}{ Viburnum acerifolium } & Herbaceous Layer & 0.250 & 0.714 & - & 0.250 & 0.250 \\
\hline & Seed Bank & - & - & - & - & - \\
\hline \multirow[t]{2}{*}{ Viburnum dentatum } & Herbaceous Layer & 0.375 & - & - & - & - \\
\hline & Seed Bank & - & - & - & - & - \\
\hline \multirow[t]{2}{*}{ Viola blanda } & Herbaceous Layer & - & 0.143 & 0.125 & 0.250 & 0.125 \\
\hline & Seed Bank & - & 0.143 & - & 0.125 & - \\
\hline \multirow[t]{2}{*}{ Viola canadensis } & Herbaceous Layer & - & - & - & 0.250 & - \\
\hline & Seed Bank & - & - & - & - & - \\
\hline \multirow[t]{2}{*}{ Viola cucullata } & Herbaceous Layer & - & - & - & 0.125 & - \\
\hline & Seed Bank & - & - & - & - & - \\
\hline \multirow[t]{2}{*}{ Viola hastata } & Herbaceous Layer & 0.125 & 0.286 & 0.250 & 0.250 & 0.500 \\
\hline & Seed Bank & - & - & - & - & - \\
\hline \multirow[t]{2}{*}{ Viola macloskeyi } & Herbaceous Layer & 1.000 & 0.857 & 0.625 & 0.750 & 0.500 \\
\hline & Seed Bank & 0.750 & 0.286 & 0.500 & 0.125 & 0.375 \\
\hline \multirow[t]{2}{*}{ Viola pubescens } & Herbaceous Layer & 0.125 & - & - & - & 0.250 \\
\hline & Seed Bank & - & - & - & - & - \\
\hline \multirow[t]{2}{*}{ Viola pubescens var. pubescens } & Herbaceous Layer & 0.125 & - & - & - & - \\
\hline & Seed Bank & - & - & - & - & - \\
\hline \multirow[t]{2}{*}{ Viola rotundifolia } & Herbaceous Layer & 0.375 & 0.143 & - & 0.125 & 0.250 \\
\hline & Seed Bank & 0.625 & 0.286 & 0.500 & 0.375 & 0.250 \\
\hline \multirow[t]{2}{*}{ Viola sororia } & Herbaceous Layer & 0.125 & 0.143 & - & - & - \\
\hline & Seed Bank & - & - & - & - & - \\
\hline Viola spp. & Herbaceous Layer & 0.750 & 0.714 & 0.750 & 0.750 & 0.750 \\
\hline & Seed Bank & 0.125 & 0.143 & 0.125 & 0.125 & 0.125 \\
\hline Vitis $L$. & Herbaceous Layer & 0.125 & 0.286 & 0.125 & 0.250 & 0.250 \\
\hline & Seed Bank & - & 0.024 & - & - & \\
\hline
\end{tabular}


